UDC 378.018.43;004.85:61

DOI: $10.52534 / \mathrm{msu}-$ pp.7(2).2021.63-69

Oleksandr I. Fediv, Inna O. Buzdugan*, Volodymyr V. Vivsianyk, Iryna V. Prysiazhniuk, Vasyl P. Prysyazhnyuk

Bukovinian State Medical University

58002, 2 Teatralna Sq., Chernivtsi, Ukraine

\title{
The Role of Moodle Software among Medical Students During Distance Learning
}

\author{
Article's History: \\ Received: 14.12 .2020 \\ Revised: 26.02 .2021 \\ Accepted: 27.04.2021
}

\section{Suggested Citation:}

Fediv, O.I., Buzdugan, I.O., Vivsianyk, V.V., Prysiazhniuk, I.V., \& Prysyazhnyuk, V.P. (2021). The role of Moodle software among medical students during distance learning. Scientific Bulletin of Mukachevo State University. Series "Pedagogy and Psychology", 7(2), 63-69.

\begin{abstract}
The study of the role of Moodle software among medical students is relevant, as distance learning is now new in terms of learning, processing, and teaching educational material online. The representation of new (latest) informative data using Moodle during distance learning contributes to and increases the level of students' knowledge. Moodle software is a valuable resource that presents an archive of educational (scientific) materials to students and teachers with unlimited access. The study is aimed at determining the role of Moodle for medical students during distance learning based on a theoretical review of the literature. Three stages of methodological justification were proposed as the basis for this study. At the first stage of the study, Moodle software was characterised; during the second - the role of distance learning was defined; third - the quality of medical students' training during distance learning through the use of innovative technologies, namely Moodle, was assessed. The study substantiates the significant role of Moodle and distance learning: understanding the goals of learning, gaining a significant "baggage" of knowledge, the latest information and access to resources, self-learning, self-improvement, and development of a "doctor" personality. The expediency of using the software among medical students is proved, taking into account the structure, logic, constant updating of materials, direct assessment of the student using test tasks and practical classes. Using Moodle software during distance learning, a medical student independently and consciously focuses on pathology based on the acquired knowledge, clearly and reasonably makes a preliminary conclusion (diagnosis) with subsequent appropriate treatment. The combined use of Moodle software and highly qualified teachers improve the quality of education and guide the medical student to focus on the study material and improve one's practical skills with the presented materials and visual aids
\end{abstract}

Keywords: Moodle, distance education, educational material, distance learning, video lectures, modernisation

\section{INTRODUCTION}

Moodle (an acronym for Modular Object-Oriented Dynamic Learning Environment) is a learning platform designed to unite teachers and students into one reliable [1], safe and integrated system for creating a personalised learning environment [2]. It provides students and teachers with a joint study of the proposed educational material, which is easy and accessible to use [3].

An analysis of recent research has shown that Moodle is the most advanced and widespread system for this purpose in Ukraine and the world. According to I.V. Stavytska, "The Moodle system has become quite popular in the world among teachers as a tool for creating dynamic courses for students. Moodle is available as open-source software. Anyone can adapt, extend or modify Moodle for commercial and noncommercial projects without any license fees" [4]. According to I.V. Stavytska, the scientist O.A. Shcherbin has repeatedly studied the Moodle system in his works. The author described the national strategy for the development of education in Ukraine for 2012-2021, proposed by the Ministry of Education and Science, which provided for the modernisation of the structure of education based on a competency approach, full implementation, and use 
of appropriate assessment system [5]. The essence of designing a Moodle-oriented virtual learning environment as a means of training specialists of socionomic professions was revealed by I.V. Lovyanova and co-authors. The dialogic interaction of the student of medical specialisation and the teacher, knowledge of various technologies, techniques, methods which solve problems of various levels of interaction in society were revealed. The results have shown that Moodle is one of the software systems that make it easier for students to solve a scientific problem through "cognitive curiosity", skills and abilities, to make hypotheses based on the acquired knowledge, and make the correct conclusion (diagnosis), etc. [6].

Many Ukrainian scientists, including K.R. Kolos [7], T.Y. Priymak, and O.O. Petrushka [8], assessed the role of Moodle system software, its positive and negative sides, and revealed its importance in various social (professional) areas. In addition to Ukrainian, foreign scientists have also considered this issue. S. Limongeli, M, Lombardi, A. Marani, F. Siarone, M. Temperini have repeatedly highlighted the role of the Moodle system in distance learning and developed recommendations to help teachers create any courses [9]. I. Mwalumbwe, J.S. Mtebe studied the basics of this study to predict the "progress" of students in this system. The authors reveal the essence of the Moodle programme and show the results of the study, that clearly outline the advantages and disadvantage of this system and its impact on student's performance [10]. However, not only the Moodle system has an impact on medical student's development but also styles of teaching. M.A. Abdullah began to develop this issue and explained the importance of Felder-Silverman's learning style models and their connection to students' learning.

Distance education is an organised learning activity where students, teachers, and learning materials from many sources come together through communication technologies. Distance education can be carried out in different forms, environments, educational institutions, at different educational levels and ages, using different technologies, teaching methods, approaches based on different philosophical and strategic concepts with one or more teachers [12].

The purpose of this study is to assess the role of Moodle software among medical students during distance learning based on a theoretical review of the literature. The following objectives have been set: to determine the advantages and disadvantages of the Moodle system, to assess distance learning and its impact on the quality of medical student's education.

\section{METHODOLOGY}

To meet the set purpose and objectives, several stages of analysis of the assessment of the studied material were proposed. The first stage of the study lies in the essence of distance learning, because it enables constant acquisition of knowledge without violating the programme plan of the medical student and the teacher. Such learning develops self-education and self-improvement of each student. At this stage of the study, the ways of presenting visual material remotely and addressing deficiencies of distance learning in practical medical classes, which require a direct relationship "patient-doctor (student)" during the consideration of topics are highlighted. The issue is important because "live communication" between medical students and patients, and discussion, clarification of unclear issues with the teacher is mandatory in understanding the practical medical material and formulating the correct conclusion (diagnosis).

The second stage of the theoretical review provides an assessment of the Moodle software as one of the available systems among medical students during distance learning. It is known that the Moodle system makes it possible to quickly and easily provide access to educational (scientific) materials without leaving the "comfort zone". It creates a "virtual" audience with students and teachers, which will allow them to independently implement their knowledge. According to the analysis of the literature, the essence of the software, its ways of content maintenance, selection of methods of presentation of educational (scientific) material, analysis of the presented material, and ways of assessment in this system are revealed.

The third stage includes assessing the quality of teaching medical students during distance learning through the use of innovative technologies, namely Moodle. A characteristic feature of the quality of medical students' education is the acquisition of the topics proposed by the working annual programme and their orienting in the diagnosis of diseases. The students' perception of scientific (educational) material, its correct presentation, and understanding of the disease will help students to clearly express their opinion on the correct conclusion (diagnosis). This issue is relevant because distance learning is now new in terms of learning, processing, and teaching educational material online. Teachers are not always able to comprehensively present and explain the subject to students, especially when it comes to the medical profile, as it is based on conventional face-to-face teaching and constantly "gaining" knowledge in practice, which is the basis in the medical field.

The object of the study is the characteristic of the students' condition, according to the literature data. The subject of the research is Moodle software, an assessment of the impact of distance learning on the quality of education of medical students.

It is rational that the application of the proposed subject of assessment will help to better understand the impact of innovative technologies and educational development of students. Assessments of literature data, both Ukrainian and foreign, will make it possible to identify the deficiencies in the use of Moodle software that are constantly encountered by both students and teachers during distance learning and to find the right approach to address them.

\section{RESULTS AND DISCUSSION}

Distance learning is a form of learning through video meetings of students and teachers, which makes it possible to increase one's scientific and professional level while still learning (working). During distance learning, a student is 
a person who independently studies the presented educational material in the approved work programme of the higher education institution, and in this case, the teacher provides educational visuals and, if possible, maximum explanation on lectures. This type of education directs the teacher to search and use new teaching aids according to the presented requirements of the educational process (Fig. 1).

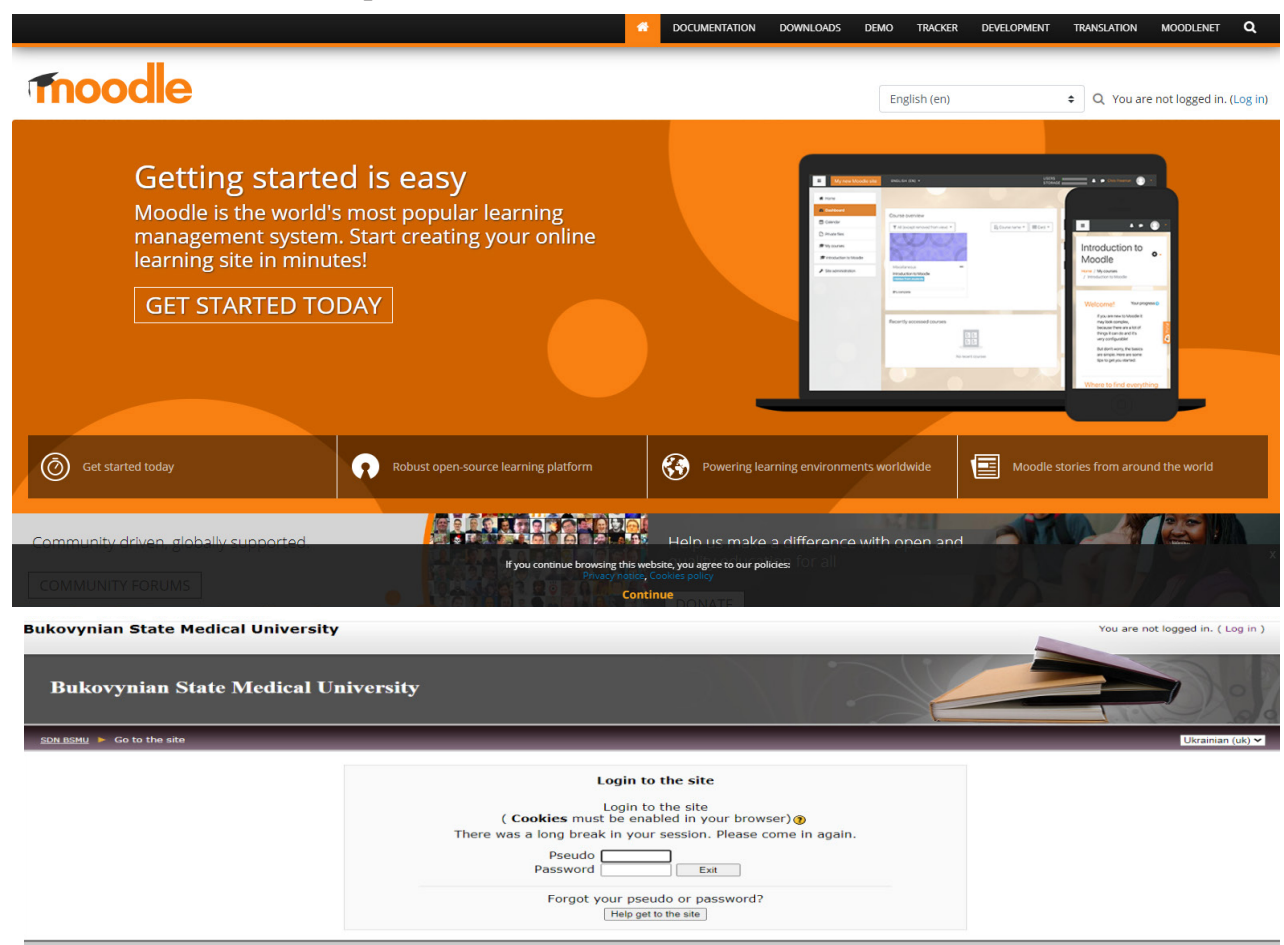

Figure 1. Learning platform "Moodle" for distance learning

The advantages of distance learning are: accessibility, informativeness, "flexibility in learning", convenience in choosing the time of the study, unlimited communication among different segments of the population and nationality in the common direction of learning material [11], the ability to constantly receive new (last 5 years) cross-border learning materials and "time saving" (no waste of time traveling and searching for study material in libraries and medical sites on the Internet), the use of large amounts of information among previously created student groups by educational institutions according to specialisations and faculties [13 ].

The effectiveness of such an educational process depends on the control of learning material, analysis of the priorities of factors influencing the presentation of material by teachers, and the work of students during distance learning. Quality control of the acquired knowledge is tested on a lecture, which helps to identify unfinished "areas" of presentation of educational material, as well as to improve the "gap zone" (to understand the material better) before the lecture is over. Distance learning itself assesses the student objectively and has greater limits of assessment than other forms of learning. Another advantage of distance learning is the variety of student assessments and encouraging him to search for the presented issues in the additional educational literature, which allows the student to expand one's horizons, learn and improve unassisted. There are many advantages of distance learning, which allows emphasising its significant role in the learning process and self-development.

However, given that the use of distance learning is based on the ability to use different software technologies, not every experienced teacher can use them. The ability to use innovative technologies and the correct presentation of visual materials to students is the key to the successful encouragement of students to learn. Among the disadvantages that may appear during the presentation of educational material, it is also worth highlighting the technical problems: the lack of Internet access in case of failure on the line; the impact of weather conditions that reduce the speed of the Internet resource with poor quality playback of audio and video materials during distance learning; lack of power supply, which is necessary for distance learning. However, the described deficiencies are temporary and do not have a pronounced negative impact on the quality of teaching and education.

In the process of teaching, the latest technologies are constantly evolving, which require their understanding and ability to use them. One of the innovative technologies in Ukraine is the Moodle software, which has become an indispensable assistant for teachers in explaining the material and assessing students. What is the function of Moodle? What are the advantages and disadvantages of this software? These are some questions that constantly arise in teachers. After all, the teacher has the direct and greatest interaction in working with the system.

This programme has a wide range of functionalities independent training of students, their learning and assessment during distance learning, the creation of additional courses for students, and their acquisition of theoretical skills during the study. The Moodle system allows teachers to create effective sites for online learning, which are used in both student learning and advanced training of the teacher [14] (Fig. 2). 


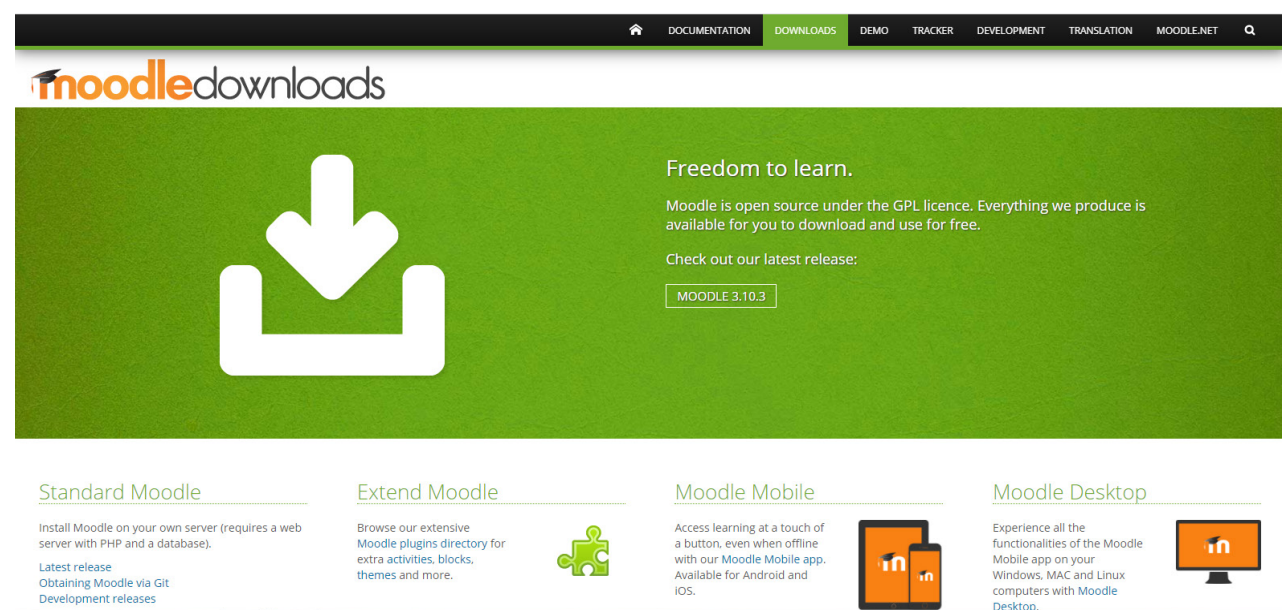

Figure 2. Methods of uploading educational materials to the educational platform

The study of therapeutical topics in accordance with the learning programmes throughout the year with the help of a system of innovative technologies (Moodle) and distance learning allows teachers to cover and present this section as much as possible. Knowing that each disease has its own period of progression (seasonality), typical and atypical clinical course, the teacher with the help of videos uploaded to the Moodle programme, can emphasise the issues that arose during the analysis of the topic at any time. This indicates the availability of educational material for teacher, student, and any other person. Availability is one of the benefits of the software.
The next advantage is "richness" and constant updating with educational (scientific) material. With the help of Moodle software, Bukovynian State Medical University has created various discussion forums, uploaded documents (or links to sites) with video and audio materials, textbooks of recent years, which describe new clinical classifications of diseases, modern research methods for the treatment of pathology. The teaching material is uploaded by the teacher constantly during the update of the literature (manuals, scientific papers), which "saves time" for each teacher in terms of preparation for the subject (Fig. 3).
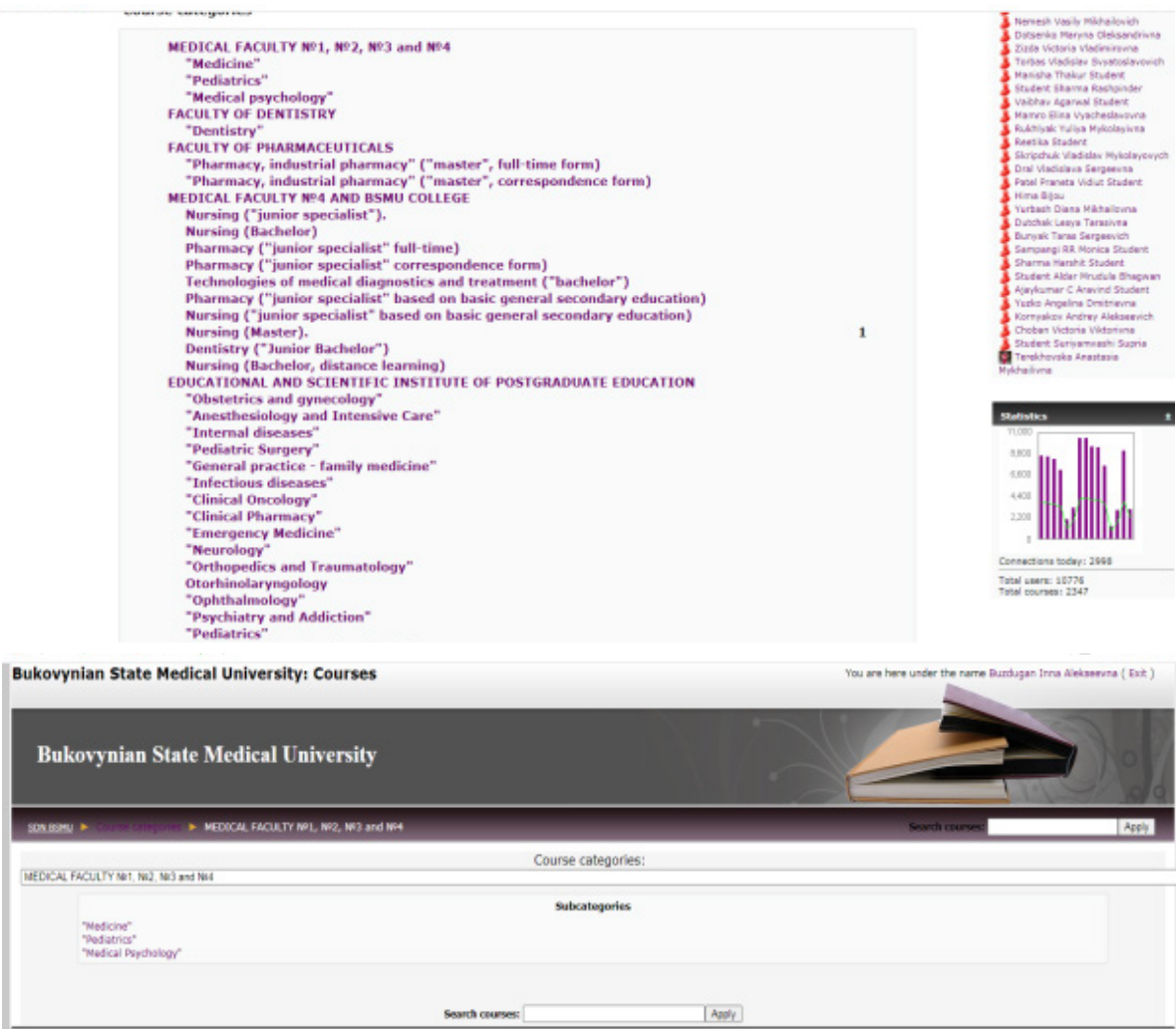

Figure 3. The educational platform of the medical educational institution of the IV level of accreditation

Each teacher can post their own previously saved and edited photos, pathogenetic diagrams, diagnostics and treatment on Moodle, which he received as a result of practice and experience. These materials have educational content and contain a visual image of the disease, its clinical manifestations with practical skills for students (percussion, 
palpation, auscultation with changes that are characteristic of each disease), as well as diagnostic criteria, differential diagnosis.

Moodle makes it possible to logically and structurally distribute the downloaded material according to previously created units (groups, faculties, specialisations), which will help to quickly find educational material for both students and teachers.

An integral part of the training with the proposed software system is the created calendar with news and announcements of educational and scientific events, as well as medical leisure. Invitations to various types of medical conferences, webinars, seminars that will expand the horizons on the proposed medical topics (links to sites for self-improvement) can be found there. This creates an opportunity for each student to enrich the "baggage of knowledge" and assess the possible development and course of any pathology with its subsequent diagnostics.

Assessing each student with Moodle software is easy by solving tests and situational tasks. This type of assessment is relevant and prioritised during distance learning. The advantages of Moodle described above and others (the ability to view the results of a distance course by a student; test results; the ability to communicate directly with the teacher; the ability to upload files with completed tasks and the ability to use reminders about events in the course), make it possible to evaluate Moodle as a significant component in education among teachers and students [15]. In addition to the positive features offered above, there are several equally important positive points in the Moodle software - the role of videos during the analysis of the topic. As is known, it is not always possible to clearly demonstrate the pathology under the topic of the lesson in medical institutions. It is the video and audio materials that are previously uploaded by the teacher and correspond to the specific topics of the lesson that will help the student to easily acquire and understand the educational material and orient in it well. Visual educational material is structured, concise and reflects the essence of the pathological process and the basis of its treatment (Fig. 4).

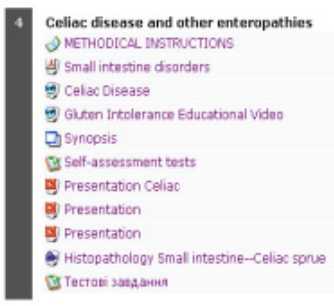

$\square$

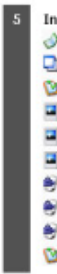

Inflammatory bowel diseases. Irritable bowel syndrome Inllammatory bowel diseas es

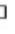
Synopis

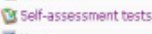
axtar a X CROHNS DISEASE

- CROHNS CURE ULCERATIVE COUTIS CURE CROHNS DISEASE COLTTIS IOS CURE SCD DIET Q CROHNS DISEASE

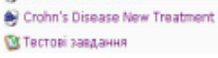

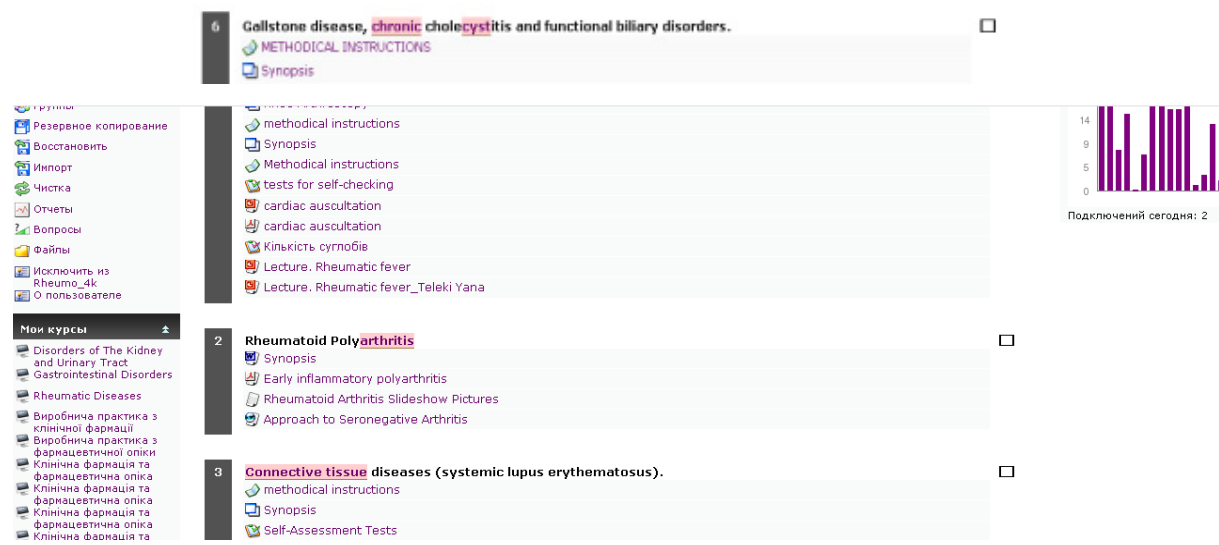

Figure 4. The educational platform of the medical educational institution of the IV level of accreditation

Google Drive and Google Calendar play an important role in distance learning using Moodle software. With Google Drive, both students and teachers can store all downloaded information from Moodle on a mobile device or PC. The calendar may also contain monthly information about the teacher's scheduled videoconferences with groups according to the curriculum. Due to the busy schedule, the function "Reminder" in Google Calendar will notify both the teacher and the student of the start of a seminar or practical session during distance learning.

However, among the advantages, there are significant disadvantages that are important in medical universities. The main and biggest drawback is the lack of practice during distance learning because practice in the medical field is a significant "action" in the analysis of the material and its understanding. In doctors' work, they 
constantly use practical skills in the form of percussion, palpation, auscultation, and "live" communication with the patient, which is essential in making a preliminary diagnosis and subsequent diagnostics (confirmation) and determining the main conclusion (diagnosis).

Experience has shown, Moodle software affects the quality of education by increasing the self-development, self-improvement, and outlook of each of the medical students, which confirms the important role of its use in educational institutions, including medical. Software is an integral part of distance learning. It is known that in 2013, in accordance with the recommendations of the Ministry of Education and Science of Ukraine, the use of distance learning in universities of III-IV levels of accreditation was approved. However, this issue has been considered since 2003 [13]. It was recognised that distance learning is a new organisation of education, which combines elements of full-time, part-time, and evening types of learning, based on the means of exchanging educational material at a distance and self-study [16].

According to the board of the Ministry of Education and Science of Ukraine, which was established in 2005, it was noted that distance learning will expand opportunities and create a single national educational and scientific [17], as well as information base of learning environment that will allow Ukraine to join European educational and scientific information resources and increase the horizons of each [18].

Using Moodle software during distance learning allows students to orient themselves in their learning. It is during distance learning that the student comprehends the importance of studying subjects, their implementation in their medical practice, the stimulus in the development of their own outlook, and goal setting in further career growth. This medical education affects not only the educational development, but also the psychological, forming the student's personal development not as a "student", but as a "doctor", "nurse", etc. Personal development together with the presentation of education help the medical student to decide on the choice of future profession and make every effort to better understand this choice.

Assessing the literature on the quality of education during distance learning using Moodle software, it can be argued that teaching the material, presenting it in the proposed programme, accessibility and ease of learning technology among both teachers and students is necessary to improve everyone's knowledge. The main advantages of this method are the richness and constant updating of educational material, access to them at any time, objective assessment of medical students during a seminar or practical lesson, presentation of visuals (practical materials) on medical topics according to the work programme, distance training without spending time on transport and without separation from the study (work). The disadvantages are insufficient technological support and technical failures of Internet suppliers. However, they are temporary with the possibility of their addressing. Such training broadens the horizons, allows self-improvement, self-development, to see and understand one's imperfections in the study of material and its presentation, understand the importance of knowledge, re-evaluate what is learned, and formulate correct conclusions. Distance learning and the Moodle system not only allow for self-development and self-learning but also assess opportunities and identify prospects for the future, which improves the quality of higher education.

\section{CONCLUSIONS}

The Moodle system in medical universities allows providing the maximum educational process during distance learning, to assess the readiness of students for the topic of the lesson, as well as to improve the presentation of educational visual materials. At the same time, medical students increase the level of understanding of the studied material and learning, the role of pathologies in the studied in the further analysis, the need for self-improvement, self-development, and opportunities of each student with further prospects.

The use of Moodle software among medical students makes it possible to quickly, efficiently, and promptly, without additional effort in finding material to prepare for a practical lesson, which improves the quality of the educational process by presenting constantly updating educational material of the past 5 years, and an individual approach to explaining the material to each of the students. However, the simultaneous use of the site by a large number of students leads to an overload of the system, which does not always allow for the timely processing of educational material or to taking testing with subsequent evaluation of the processed material. Therefore, the state of the Moodle system with a large number of users is one of the issues of further research.

\section{REFERENCES}

[1] Mikhailova, N.V. (2012). Moodle e-learning environment as a means of organizing asynchronous independent work of university students (Doctoral thesis, Orenburg State University, Orenburg, Russian Federation).

[2] Budanov, V.G. (2007). Management of the educational process in modern conditions: innovations and problems of modeling. In Synergetic paradigm. Synergetics of education (pp. 450-469). Moscow: Progress-Tradition.

[3] Osadcha, K.P., Osadchy, V.V. (2014). Technologies of distance learning. Working with Moodle 2.4. Melitopol: B. Khmelnitsky Melitopol State Pedagogical University.

[4] Trius, Yu.V., Herasymenko, I.V., \& Franchuk, V.M. (2012). The system of electronic education of higher educational institutions on the basis of Moodle. Cherkasy: Cherkasy State Technological University.

[5] Stavytska, I.V. (2014). Moodle system as a means of improving the effectiveness of teaching. In Modern Approaches and Innovations in foreign languages teaching: Proceedings of the IX international scientific and practical conference (pp. 139-141). Kyiv: NTUU "KPI".

[6] Lovyanova, I.V., Armash, T.S., Bobylev, D.E., \& Krasnoshchok, A.V. (2018). The Moodle system as a training tool for specialists of socionomic professions. New Computer Technology, XVI, 194-204. Scientific Bulletin of Mukachevo State University. Series "Pedagogy and Psychology", Vol. 7, No. 2 
[7] Kolos, K.R. (2011). Moodle system as a means of development of subject competences of teachers of computer science in the conditions of distance postgraduate education (Doctoral dissertation, National Academy of Pedagogical Sciences of Ukraine, Kyiv, Ukraine).

[8] Primak, T.Yu., \& Petrusha, O.O. (2015). Methodical recommendations for the development of e-learning course. Kyiv: NUFT.

[9] Limongelli, C., Lombardi, M., Marani, A., Sciarrone, F., \& Temperini, M. (2016). A recommendation module to help teachers build courses through the Moodle Learning Management System. Journal New Review of Hypermedia and Multimedia, 22, 58-82. doi: 10.1080/13614568.2015.1077277.

[10] Mwalumbwe, I., \& Mtebe, J.S. (2017). Using learning analytics to predict students' performance in Moodle Learning Management System: A case of Mbeya University of Science and Technology. Electronic Journal of Information Systems in Developing Countries, 79(1), 1-13. doi: 10.1002/j.1681-4835.2017.tb00577.x.

[11] Abdullah, M.A. (2015). Learning style classification based on student's behavior in Moodle Learning Management System. Transactions on Machine Learning and Artificial Intelligence, 3(1), article number 28. doi: 10.14738/tmlai.31.868.

[12] Shcherbyna, O.A. (2016). New tools of competencies evaluation in Moodle. Information Technologies and Learning Tools, 55(5), 96-104. Retrieved from http://nbuv.gov.ua/UJRN/ITZN_2016_55_5_10.

[13] Vyshnivskyi, V.V., Hnidenko, M.P., Haidur, H.I., \& Ilin, O.O. (2014). Organization of distance learning. Creation of electronic training courses and electronic tests. Kyiv: DUT.

[14] Resolution of the Cabinet of Ministers of Ukraine No. 466 "On Approval of the Regulation on Distance Learning". (2013, April). Retrieved from http://zakon4.rada.gov.ua/laws/show/z0703-13.

[15] Shcherbyna, O.A. (2015). Assessment of competencies by means of the Moodle platform. Information Technologies and Learning Tools, 45(1), 134-145.

[16] Khusainova, A.A. (2013). Pedagogical conditions of using learning management sustem Moodle in the organization of individual work in foreign language teaching students of economic specialties. Modern Studies of Social Issues, 2(22). doi: 10.12731/2218-7405-2013-2-37.

[17] Order of the Ministry of Education and Science of Ukraine No. 466 "Regulations on Distance Learning”. (2013, April). Retrieved from https://zakon.rada.gov.ua/laws/show/z0703-13\#Text.

[18] Decision of the Board of the Ministry of Education and Science of Ukraine No. 6/2-4 "On the State and Prospects of Distance Learning in Ukraine”. (2005, June). Retrieved from http://www.osvita.org.ua/distance/pravo/04.html.

\section{Олександр Іванович Федів, Інна Олексіївна Буздуган, Володимир Васильович Вівсянник, Ірина Василівна Присяжнюк, Василь Петрович Присяжнюк}

Буковинський державний медичний університет

58000, пл. Театральна, 2, м. Чернівці, Україна

\section{Роль програмного забезпечення Moodle серед студентів медичного спрямування під час дистанційного навчання}

Анотація. Вивчення ролі програмного забезпечення Moodle серед студентів медичного спрямування $\epsilon$ актуальним, оскільки дистанційне навчання нині $€$ новим щодо засвоєння, опрацювання навчального матеріалу та його викладання у режимі онлайн. Репрезентація нових (новітніх) інформативних даних за допомогою програми Moodle під час дистанційного навчання сприяють і підвищують рівень знань студентів. Програмне забезпечення Moodle - цінний ресурс, що містить архів навчальних (наукових) матеріалів для представлення студентам i викладачам із необмеженим доступом. Мета дослідження полягала у визначенні ролі програмного забезпечення Moodle серед студентів медичного спрямування під час дистанційного навчання на підставі теоретичного огляду літератури. В основу поставленої мети було запропоновано три етапи методологічного обгрунтування. На першому етапі дослідження охарактеризовано програмне забезпечення Moodle; під час другого - визначено роль дистанційного навчання; третього - оцінено якість навчання студентів-медиків під час дистанційного навчання за допомогою використання інноваційних технологій, а саме Moodle. У статті обгрунтовано значну роль програми Moodle та дистанційного навчання: осмислення поставлених цілей у навчанні, отримання значного «багажу» знань, новітньої інформативності та доступності до ресурсів, самонавчання, самовдосконалення й формування особистості «лікар». Доведено доцільність застосування програмного забезпечення серед студентів медиків, враховуючи структурованість, логічність, постійне оновлення матеріалів, безпосереднє оцінювання студента шляхом тестових завдань і практичних занять. За допомогою програмного забезпечення Моодle під час дистанційного навчання студент медичного спрямування самостійно та усвідомлено зорієнтується у патології на основі отриманих знань, чітко та обгрунтовано попередньо поставить висновок (діагноз) із подальшим відповідним лікуванням. Поєднане застосування програмного забезпечення системи Мооdle та висока кваліфікація викладачів підвищують якість освіти і спрямовують студента-медика добре орієнтуватися у навчальному матеріалі й підвищувати свої практичні навички представленими матеріали та наочностями

Ключові слова: Moodle, дистанційна освіта, навчальні матеріали, дистанційне навчання, відеолекції, модернізація

Scientific Bulletin of Mukachevo State University. Series "Pedagogy and Psychology", Vol. 7, No. 2 